\title{
IMPLICAÇÕES SOCIOAMBIENTAIS E AÇÕES DE RESPONSABILIDADE SOCIOAMBIENTAL DA INDÚSTRIA DE CERÂMICA VERMELHA NA REGIÃO METROPOLITANA DO CARIRI - CE
}

\section{Christiane Bezerra Alves}

Universidade Regional do Cariri (URCA)

Crato - Ceará - Brasil

E-mail: chrisluci@gmail.com

ORCID: http://orcid.org/0000-0001-5987-6814

\author{
Ahmad Saeed Khan \\ Universidade Federal do Ceará (UFC) \\ Fortaleza - Ceará - Brasil \\ E-mail: saeed@ufc.br \\ ORCID: http://orcid.org/0000000000000 \\ Patrícia Verônica Pinheiro Sales Lima \\ Universidade Federal do Ceará (UFC) \\ Fortaleza - Ceará - Brasil \\ E-mail:pvpslima@gmail.com \\ ORCID: https://orcid.org/0000-0002-6622-3640
}

Recebido em: 27/07/2021. Aprovado em 09/09/2021

DOI: http://dx.doi.org/10.5380/guaju.v7i2.80713

\section{Resumo}

Esse artigo propõe um estudo do setor de cerâmica da Região Metropolitana do Cariri (RM Cariri) - CE (Brasil), através da caracterização do segmento em questão, com especial destaque para a identificação dos vínculos socioambientais estabelecidos e das ações de responsabilidade socioambiental empreendidas. O setor em análise tem, reconhecidamente, alto impacto ambiental negativo; as principais fontes de matéria-prima têm origem mineral (argila) e vegetal (lenha). A área proposta para análise é formada por nove municípios (Barbalha, Caririaçu, Crato, Farias Brito, Jardim, Juazeiro do Norte, Missão Velha, Nova Olinda e Santana do Cariri) localizados no sul do estado do Ceará e apresenta reconhecida diversidade de sistemas e subsistemas naturais. A presença de forte conurbação urbana, principalmente relativa a áreas como o triângulo Crajubar (Crato, Juazeiro do Norte e Barbalha), resulta em larga ação antrópica sobre as condições 
ambientais. A pesquisa se baseou na aplicação de questionário junto à população de indústrias de cerâmica vermelha na região, correspondente, no segundo semestre de 2016, a 19 empresas pesquisadas.

Palavras-chave: Dinâmica produtiva. Processo de trabalho. Cerâmica vermelha. Implicações socioambientais.

\title{
Socio-environmental implications and social and environmental responsibility actions of the red ceramic industry in the Metropolitan Region of Cariri - CE
}

\begin{abstract}
This paper proposes a study of the ceramics sector of the Cariri Metropolitan Region (RM Cariri) - CE (Brazil), through the characterization of the segment in question, with special emphasis on the identification of the socio-environmental links established and the socioenvironmental responsibility actions undertaken. The sector under analysis is known to have a high negative environmental impact; the main sources of raw material are mineral (clay) and vegetable origin (firewood). The proposed area for analysis is formed by nine municipalities (Barbalha, Caririaçu, Crato, Farias Brito, Jardim, Juazeiro do Norte, Missão Velha, Nova Olinda and Santana do Cariri) located in the south of the State of Ceará and presents a recognized diversity of natural systems and subsystems. The presence of strong urban conurbation, mainly related to areas such as the Crajubar triangle (Crato, Juazeiro do Norte and Barbalha), results in large anthropic action on environmental conditions. The research was based on the application of a questionnaire to the population of red ceramic industries in the region, corresponding, in the second half of 2016, to 19 companies surveyed. Keywords: Productive dynamics. Work process. Red ceramics. Social and environmental implications.
\end{abstract}




\section{Introdução}

As atividades da indústria de cerâmica são marcadas por um conjunto de intervenções que interferem nas características naturais do meio ambiente. Caracterizam-se pela influência cotidiana da legislação ambiental, são moldadas pelas questões ambientais de âmbito global, como a influência climática decorrente de diferentes etapas de seu processo produtivo (FIGUEIREDO; SOUSA, 2013). No âmbito sistêmico, tem efeitos estruturais, estéticos e sanitários nos recursos naturais (água, solo, vegetação e ar); segurança, saúde e bem-estar da população; atividades sociais e econômicas e, de modo geral, em padrões de desenvolvimento de uma sociedade.

Tal conjunto de fatores remete-nos à identificação de aspectos e impactos ambientais decorrentes de tais atividades. Ao mesmo tempo, um rol de medidas mitigadoras deve acompanhar indústrias com elevado passivo ambiental, criando suporte para a implementação de um quadro de boas práticas ambientais.

Através deste trabalho, propõe-se um estudo do setor de cerâmica da Região Metropolitana do Cariri (RM Cariri) - CE, através da caracterização do segmento em questão, com especial destaque para a identificação dos vínculos ambientais estabelecidos. Pretende-se, portanto, identificar as principais implicações socioambientais decorrentes da atividade de cerâmica vermelha na região, bem como as ações de responsabilidade socioambientais implementadas por parte das empresas. Considera-se, aqui, que o conceito de responsabilidade socioambiental propõe uma cultura organizacional fundamentada em três grandes princípios: a) uma relação ética e transparente da empresa com todas as partes interessadas (stakeholders); b) um compromisso com uma produção sustentável, refletido num ambiente ecologicamente equilibrado e socialmente justo, que vai além das exigências e demandas legalmente constituídas; c) atuação em sintonia com o desenvolvimento sustentável.

O setor em análise tem, reconhecidamente, alto impacto ambiental negativo; as principais fontes de matéria-prima têm origem mineral (argila) e vegetal (lenha). A extração da argila promove desmatamento acelerado, degradação do solo e desbarrancamento de matas ciliares; o consumo da lenha contribui para a devastação das matas nativas e a queima de produtos gera emissão em quantidades apreciáveis de certos componentes gasosos como: monóxido de carbono (CO), óxidos de nitrogênio (NOx), óxidos de enxofre (SOx), amônia (NH3) e metano ( $\mathrm{CH} 4)$. O caráter invasivo e os impasses impostos ao meio ambiente reconfiguram paisagens e constituem ameaças à fauna presente nas regiões 
de exploração da atividade. Grande parte do processo produtivo tem efeito sobre o meio ambiente, equipamentos, ferramentas e saúde humana (BEZERRA; VIANA; FARIA JR., 2001; LINARD, KHAN, LIMA, 2015; SILVA; MEDEIROS, 2011; SOUSA et al., 2006), seja da população diretamente ligada à atividade ou a que se encontra próxima a locais de exploração da matéria-prima ou fabricação dos produtos, tendo implicância, ainda, no aquecimento global.

A área proposta para análise é a Região Metropolitana do Cariri (RM Cariri), formada por nove municípios (Barbalha, Caririaçu, Crato, Farias Brito, Jardim, Juazeiro do Norte, Missão Velha, Nova Olinda e Santana do Cariri), os quais ocupam cerca de 5.025,655 km² do estado do Ceará, onde vivem de 564.478 habitantes (divididos entre 21,1\% de população rural e 78,9\% urbana) (IBGE, 2010). Vale ressaltar que a área apresenta reconhecida diversidade de sistemas e subsistemas naturais e que a presença de forte de conurbação urbana, principalmente relativa a áreas como o triângulo Crajubar (Crato, Juazeiro do Norte e Barbalha), resulta em larga ação antrópica sobre as condições ambientais, resultando em fragilidades e riscos que prejudicam o equilíbrio sócio-econômico-ambiental da região.

A pesquisa levou em conta um marco exploratório-descritivo e baseou-se na aplicação de questionário junto à população de indústrias de cerâmica vermelha da RM Cariri, correspondente, no segundo semestre de 2016, a 19 empresas pesquisadas (total das empresas no setor). Como suporte teórico, destacam-se, aqui, reflexões sobre os desafios corporativos e a responsabilidade socioambiental.

O trabalho encontra-se dividido em cinco seções, além desta introdução. Na segunda seção, são apresentados aspectos teóricos e estratégias de promoção da responsabilidade socioambiental; a seção três destaca um conjunto de pesquisas relativas às implicações socioambientais, desenvolvidas junto ao segmento de cerâmica vermelha; na seção quatro, elencam-se os aspectos metodológicos da pesquisa; os aspectos produtivos, implicações ambientais e ações de responsabilidade socioambiental no segmento são discutidas na quinta seção deste ensaio. Por fim, apresentam-se as considerações finais.

\section{Desafios corporativos e a responsabilidade socioambiental: notas teóricas para reflexões}

No campo ambiental, as demandas de clientes e sociedade, particularmente no que concerne à conservação de ecossistemas e à integração de elementos em prol de um crescimento sustentável, fazem com que as organizações industriais atentem para a 
necessidade de gerenciamento de seus processos, a fim de mitigar ou eliminar impactos ambientais negativos. Nesse sentido, a mudança de expectativa dos stakeholders tem exigido uma atuação proativa pela revisão dos sistemas econômicos das empresas, de forma que sejam repensados os paradigmas de gestão e competitividade empresarial. O conjunto de metodologias e estratégias que compõem o novo modelo de intervenção e de relacionamento com o ambiente natural passa a caracterizar o chamado sistema de gestão ambiental.

Na literatura recente, são empreendidos esforços para que modelos sistematizem estratégias de promoção da responsabilidade socioambiental.

O trabalho de Epstein e Roy (2001) apresenta um modelo que relaciona elementos de estratégia corporativa e ações de sustentabilidade (ações sociais/ambientais) ao desempenho financeiro, ou seja, aos resultados operacionais obtidos pelas organizações. As estratégias de negócios e as análises de custo-benefício devem incorporar as ações de sustentabilidade (estratégias, planos, estruturas, sistemas, medidas), as quais se constituem peça primordial para determinar a performance financeira de longo prazo das empresas.

Os objetivos corporativos são tomados com base em princípios, metas e compromissos que levam em consideração demandas e necessidades dos stakeholders, cujo feedback determina, por sua vez, as estratégias e a busca de sustentabilidade das empresas.

Epstein e Roy (1998) chamam atenção para a importância na atuação corporativa do sistema de gestão ambiental, na medida em que é fundamental para a identificação e gerenciamento dos riscos e obrigações ambientais, contribuindo, portanto, para melhoria de desempenho, abordagem que deve envolver planejamento, operação e intervenções práticas, acompanhamento, medidas corretivas e desempenho. Porém, ainda segundo os autores, para que aspectos sociais e ambientais consigam ser enquadrados na estratégia empresarial, deve-se estabelecer uma justificativa de negócios para o bom desempenho socioambiental (EPSTEIN; ROY, 2003), já que padrões de conduta e gestão ambiental são vulneráveis, estando sujeitos a mudanças de prioridade da gerência e a ciclos financeiros das empresas.

Em Abreu, Figueiredo Jr. e Varvakis (2002), os autores trabalham um modelo do tipo estrutura - conduta - desempenho voltado para o padrão de conduta ambiental das empresas. O modelo tem como pressuposto as recomendações de Elkington (1999), que sugere os três pilares para a sustentabilidade - ambiental, econômico e social - através do Triple Bottom Line (TBL). Envolve pessoas, planeta e lucro, cujos fundamentos devem ser perseguidos pelas organizações, as quais devem avaliar impactos sobre meio ambiente 
e sociedade, além do return over investiment. O princípio básico do TBL consiste em "aproveitar os recursos do setor privado nestes novos imperativos sociais e econômicos, sem comprometer o meio ambiente, e idealmente aumentar os rendimentos econômicos e criar valor para a empresa" (ABREU; FIGUEIREDO JR.; VARVAKIS, 2002, p. 1).

Pelo modelo de Avaliação Estratégica Estrutura - Conduta - Performance Ambiental (ECP ambiental), "a performance ambiental de uma empresa é o reflexo de suas práticas competitivas ou padrões de conduta ambiental que, por sua vez, dependem da estrutura de mercado em que está inserida" (ABREU; FIGUEIREDO JR.; VARVAKIS, 2002, p. 1).

Fundamentado no conceito de causalidade, as três dimensões de conduta/ performance convergem a um resultado final triplo, elevando resultados sociais e ambientais à mesma categoria dos econômicos. Na base da estrutura de causalidade, identifica-se a ação de forças externas, como expectativas de stakeholders, marcos regulatório-institucionais, transformações tecnológicas etc. (ação governamental, inovações tecnológicas, mudanças no comportamento social) e na dinâmica do modelo, consideram-se feedbacks internos.

Uma larga corrente de autores passa a considerar a Responsabilidade Social Corporativa como toda a forma de contribuição do ambienteempresarial ao desenvolvimento sustentável, referendando-se nas dimensões expressas pelo triple bottom line (CHEN; NEWBURRY; PARK, 2009; MAON; LINDEGREEN; SWAEN, 2010).

Nessa perspectiva, Amaral (2005) elenca fatores mobilizadores para atitudes proativas por parte das empresas, no sentido de fazer parte de suas estratégias a consonância com o desenvolvimento sustentável: melhor percepção e adaptação a choques e mudanças externas; melhor resposta e sintonia com as expectativas dos stakeholders; diminuição de impactos ambientais, sociais e econômicos nos projetos; melhor gestão de custos em consequência do uso mais eficiente de recursos.

Muir e Chan (2002) enfatizam a necessidade de compromisso da empresa com o desenvolvimento e com a implementação de uma estratégia de sustentabilidade, sendo imprescindível a explanação de como o gerenciamento da sustentabilidade pode ser fundamental para o sucesso dos negócios. $\mathrm{Na}$ análise proposta pelos autores, destaque para o peso das forças externas, mobilizadoras da sustentabilidade nos negócios e para o ambiente externo, no qual se dá o exercício da cidadania corporativa. Importante enfatizar que os programas implementados recebem influência das forças externas, do conjunto de stakeholders, sendo esse conjunto de relações sistêmicas os elementos preponderantes para a manutenção e equilíbrio da sustentabilidade. 
A incorporação dos preceitos do desenvolvimento sustentável no ambiente corporativo se torna explícita no trabalho desenvolvido por Steurer et al. (2005). Isso demanda a necessidade de uma Gestão de Relacionamento dos Stakeholders (SRM - Stakeholder Relations Management), que se transforma no mecanismo no qual a empresa é confrontada com as demandas de desenvolvimento econômico, social e ambiental destes stakeholders, internalizando, portanto, as dimensões do desenvolvimento. A sustentabilidade corporativa passa a ser o conceito que orienta a existência da organização.

Para os autores, a incorporação dos princípios de sustentabilidade às práticas empresariais pode ocorrer através da responsabilidade social corporativa, abordagem que culmina em sistemas e mecanismos de gerenciamento, como as normas ISO'. Como enfatizam, a norma ISO 9000 contempla a dimensão econômica, a ISO 14001 confere à gestão ambiental o plano já assumido pela gestão da qualidade e os padrões internacionais da dimensão social são representados pela Social Accountability(SA). Apesar de não integrados, esses mecanismos interagem através da SRM.

Cabe ressaltar que a SRM caracteriza uma nova dimensão proposta por Steurer et al. (2005) (requisitos de segunda ordem), que contempla, na dinâmica das relações business - stakeholders, os princípios de transparência, reflexividade, participação, integração e intergeração e ao contemplar a sinergia dessas relações, confere a dinamicidade do próprio sistema, integrando as diferentes dimensões da sustentabilidade.

Importante observar que, no contexto de elevada concorrência e integração internacional, o modelo chama atenção para os esquemas de certificação internacional. Particularmente, a série ISO 14000 orienta um conjunto de questões ambientais, envolvendo sistema de gestão ambiental, auditorias, rotulagem e declarações ambientais, avaliação de desempenho ambiental, análise de impactos ambientais, entre outros (VALLE, 2002). Para Ashley et al. (2012), a responsabilidade social tem por princípio a busca da ecoeficiência, integrando, para isso, fatores como tecnologias, processos, produtos, recursos, pessoas e sistemas de gestão.

\footnotetext{
1 As normas ISO (International Organization for Standartization), através do Organismo Internacional Não Governamental com sede em Genebra (Suíça), representada no Brasil pela Associação Brasileira de Normas Técnicas (ABNT), constituem um conjunto de normas internacionais para atender às especificidades das organizações, sendo referências para o gerenciamento da qualidade de forma geral e constituindo-se, portanto, num sistema de certificação empresarial.
} 
O peso dos stakeholders é enfatizado por Freeman et al. (2010), que reconhecem a determinante influência dos argumentos dos stakeholders sobre os processos operacionais e a necessidade do planejamento orientado por estes, integrando objetivos econômicos, sociais, ambientais e políticos.

As análises de Maon, Lindgreen e Swaen (2008; 2010) atribuem forte relevância para a construção de uma agenda estratégica de Responsabilidade Socioempresarial (RSE), que pressupõe um alinhamento estratégico das ações de RSE com a missão e a cultura da empresa. A análise perpassa o entendimento de um dual loop que envolve percepção dos gestores, integração sob a perspectiva dos stakeholders e desenvolvimento e implantação das iniciativas de RSE. Desta forma, os processos que envolvem a aplicação e integração da RSE nas estruturas e atividades organizacionais são sobrepostos, dinâmicos e sistêmicos.

Na mesma perspectiva da RSC estratégica, fortemente ligada à teoria dos stakeholders, a contribuição de Porter e Kramer (2002; 2006) ressalta como as empresas podem se beneficiar e, ao mesmo tempo, beneficiar seus stakeholders, a partir do alinhamento estratégico de suas práticas. O direcionamento estratégico envolve políticas e práticas de operação para que as empresas desenvolvam ações sociais que convirjam com os interesses dos acionistas, criando uma área de maximização dos benefícios. As novas práticas implementadas devem aumentar a competitividade das firmas e, ao mesmo tempo, garantir melhores condições econômicas e sociais para as comunidades nas quais operam, no processo caracterizado pelos autores de criação de valor compartilhado (creating shared value) (PORTER; KRAMER, 2011).

Os autores González-Benito e González-Benito (2006) apresentam estudo identificando fatores determinantes para a prática ambiental nas organizações, divididos em três grupos principais: características organizacionais (tamanho da empresa e acesso a recursos, origem do capital, posição na cadeia de valor, atitudes estratégicas etc.), fatores externos e pressão das partes interessadas (stakeholders). A operacionalização ocorrerá através de estratégias de planejamento e organização (via sistema de gestão ambiental); comunicação (empresa-ambiente social) e a execução de operações ambientalmente corretas (produtos e processos).

Cabe acrescentar que, para os autores, o peso dos fatores na proatividade ambiental pode ser potencializado conforme estabelecidas as interações entre os determinantes. Logo, o grau de internacionalização de uma empresa pode influenciar, por exemplo, opções de articulação via mercado (como tendência de oligopolização), que por sua vez podem 
determinar mudanças de operações internas às empresas. Também, as expectativas dos stakeholders podem motivar processos de regulamentação por parte do Estado, forçando revisão nas estratégias de planejamento e gestão ambiental. O sentido reverso pode ser considerado; assim, práticas organizacionais e comunicacionais têm o potencial de influenciar o desempenho do negócio, alterando expectativas e reduzindo a pressão de stakeholders. Desta forma, reforça-se que as empresas se posicionam frente às questões socioambientais através de um contínuo reatividade-proatividade.

Vale considerar que a proatividade ambiental, conforme González-Benito e González-Benito (2006), corresponde a ações voluntariamente desenvolvidas por organizações de modo a minimizar o impacto ambiental de seus processos e operações, através de intervenções que vão além das exigências legalmente constituídas.

Tendo como referência as proposições de González-Benito e González-Benito (2005), para Abreu et al. (2013), conhecer visões e demandas dos stakeholders, incorporando os princípios de integridade, respeito, transparência e responsabilidade, constituem-se elementos catalizadores de estratégias proativas de RSC. Nesse processo, são explicativos da proatividade ambiental (ABREU; CASTRO; LÁZARO, 2013, p. 24):

\footnotetext{
a crescente conscientização ambiental da sociedade e a respectiva temeridade da organização com respeito às questões de imagem e reputação, o efeito da otimização operacional advindo das práticas de eficiência ambiental e, por fim, os questionamentos éticos com que se deparam os proprietários, gestores e acionistas das companhias a que estão relacionados.
}

O estudo de Volpon e Macedo-Soares (2007, p. 393) é parte da constatação de que "a dimensão relacional voltada para a responsabilidade socioambiental tem sido pouco investigada pelos estudiosos em gestão estratégica". Ou seja, as autoras entendem a importância de se conduzirem análises estratégicas sob a ótica sistêmica, integrativa e relacional. Isso deve ser perseguido incorporando elementos socioambientais na estratégia corporativa e a ferramenta fundamental é a formação de alianças e redes entre os diferentes segmentos em conexão com as empresas. Para isso é imprescindível a realização de alianças socioambientais, como já refletido em diferentes literaturas (BERGER; CUNNINGHAM; DRUMWRIGHT, 2004; GULATI, 1998; HARTMAN; STAFFORD, 1998), aqui expressas pelas autoras 
como formas de relacionamento entre empresas envolvendo troca, compartilhamento ou co-desenvolvimento de produtos, tecnologia ou serviços, com o objetivo de implementar políticas e atividades que incluem pelo menos um parceiro sem fins lucrativos e objetivos não-econômicos, isto é, objetivos voltados para a melhoria do bem-estar social e para a preservação do meio ambiente (VOLPON; MACEDO-SOARES, 2007, p. 396).

Volpon e Macedo-Soares (2007, p. 415) destacam, ainda, que as alianças socioambientais têm importância considerável "para alavancar forças e explorar oportunidades, bem como para atenuar fraquezas e minimizar ameaças geradas pelos fatores macroambientais, atores estratégicos e fatores organizacionais".

Para Angel (1999), a gestão tipicamente ambiental não tem sido plenamente incorporada como parte das estratégias corporativas, que geralmente se resumem às áreas de custo, qualidade, serviço, flexibilidade, e agilidade, mesmo diante de fortes pressões e demandas externas de legisladores, reguladores, clientes, consumidores finais, comunidades locais, entre outros. Nesse sentido, Angel e Klassen (1999) propõem um modelo que incorpora a visão ambiental sistêmica. As demandas relacionadas à estrutura de operação e às demandas de infraestrutura fundamentam o sistema de produção e se inter-relacionam em um ciclo de melhoria contínua.

O sistema de produção encontra-se integrado ao meio ambiente natural através de um mecanismo de realimentação, estando presente o gerenciamento das operações em todas as interligações. Desta forma, para as autoras, a questão ambiental atende aos requisitos para ser considerada uma prioridade competitiva das empresas.

\section{Setor ceramista e as pesquisas relativas às implicações socioambientais}

Com o objetivo de avaliar os principais impactos ambientais resultantes do processo produtivo da indústria cerâmica de Pedreira - SP, com a finalidade de sugerir instrumentos que possam promover a sustentabilidade socioeconômica e ecológica da atividade, Souza (2003) relaciona significativos danos ambientais, associados prioritariamente à ausência de um programa de gestão ambiental, em nível industrial e municipal.

O estudo de Soares e Nascimento (2007) avalia a influência do processo produtivo e das tecnologias empregadas no setor para a qualidade final de peças cerâmicas produzidas no estado do Piauí e identificam a seleção de argilas e as melhorias no processo de conformação como importantes elementos para a qualidade apresentada, principalmente 
por telhas prensadas, que apresentam melhores propriedades tecnológicas e estéticas. O segmento de cerâmica vermelha é investigado a partir de um estudo de caso em uma indústria da região do Seridó - RN, através do uso de uma Matriz interativa de Leopold, para medição de impactos ambientais.

O trabalho de Nascimento (2007) aponta, em destaque, perdas na qualidade do ar, ruídos indesejáveis, alterações no microclima, empobrecimento do solo, eliminação da cobertura vegetal, êxodo rural, crise na agricultura e pecuária, contaminação de águas superficiais e subterrâneas e riscos de doenças profissionais e acidentes de trabalho como os principais impactos ocorridos nas fases de implantação e operação da empresa, em especial. Um conjunto de medidas mitigadoras é sugerido, bem como um programa de acompanhamento e monitoramento de gestão ambiental.

O trabalho de Silva (2007) avalia o impacto ambiental da expansão da indústria de cerâmica vermelha no município de Carnaúba dos Dantas - RN. Aponta para a insustentabilidade da atividade ceramista, vista a partir da interação natureza-sociedade, destacando-se as relações sociais de produção ou dimensões da condição humana. Para o autor, as degradações ambientais geradas pela atividade não podem ser dissociadas dessas relações, condição para que seja pensada a equidade socioambiental e a promoção do DS.

A pesquisa de Silva e Medeiros (2011) procura identificar os impactos socioambientais gerados pela indústria de cerâmica no município de Encanto - RN e identifica grande passivo ambiental, associado ao desgaste acelerado dos solos de onde é retirada a matéria-prima para a produção dos tijolos e telhas, além do desmatamento e da poluição do ar, decorrentes da queima de lenha para geração de energia. Notam, ainda, as péssimas condições de trabalho e falta de equipamentos de segurança no processo de produção da cerâmica no município.

A implantação do Parque Nacional da Serra de Itabaiana - Parnasi, em Sergipe, é o pano de fundo para o entendimento de como olarias e cerâmicas da região reagem à criação do mesmo, em suas estratégias econômicas e capacidade de atendimento de exigências legais, no trabalho de Figueiredo (2011). Considerando-se a criação do parque como um marco da inserção da região no contexto global da modernidade, em suas ações para o DS, o estudo insere as unidades produtivas no entendimento de possíveis recriações de desigualdades sociais, evidenciando os conflitos socioambientais oriundos do processo de institucionalização do Parnasi, na medida em que "invisibiliza" os atores sociais do entorno. 
Em Pessoa (2004), são identificadas as tecnologias e as técnicas implementadas na indústria de cerâmica de Russas, na perspectiva do desenvolvimento sustentável, e acabase por concluir que o setor apresenta sustentabilidade comprometida em termos sociais, econômicos e ambientais. O estudo sugere um conjunto de novas técnicas, particularmente melhoradoras de impactos ambientais, bem como o aprimoramento das formas de gerenciamento, redução de custo e aumento da qualidade dos produtos em geral. Silva (2009) estuda o processo de fabricação de tijolos cerâmicos, na perspectiva do meio ambiente, energia e qualidade no setor para o estado do Ceará. Conclui apontando a necessidade da organização regional em polos, arranjos produtivos e entidades, de forma a promover o desenvolvimento da indústria através da cooperação mútua, do compartilhamento de tecnologias e de ações comerciais em parceria.

Em Linard (2011), são investigados os impactos causados pela indústria de cerâmica ao meio ambiente e às populações que moram no entorno onde as atividades são desenvolvidas, no município de Crato - $C E$, com destaque para a elaboração de índices de qualidade de vida da população, índice ambiental da área e de sustentabilidade da indústria de cerâmica vermelha. Conclui-se que o setor cerâmico contribui tanto positivamente quanto negativamente para a qualidade de vida dos entrevistados, com carência, principalmente nas variáveis ligadas ao lazer e renda. São identificados fortes impactos ambientais decorrentes da atividade, destacando-se a descaracterização da paisagem natural e a degradação do meio ambiente causada pelo elevado consumo dos recursos naturais, decorrente da falta de planejamento sustentável. Porém, de maneira geral, sinaliza-se alguma reação do empresariado local às pressões ambientais, com a adoção de medidas preventivas e mitigadoras dos efeitos causados por suas atividades.

\section{Notas metodológicas para análise das implicações socioambientais e das ações de responsabilidade socioambiental empreendidas pelas empresas do setor de cerâmica vermelha da RM Cariri}

A pesquisa baseou-se na coleta e análise de dados primários, obtidos por meio de visitas de campo e aplicação de questionários junto à população de indústrias de cerâmica vermelha da RM Cariri, correspondente, no segundo semestre de 2016, a 19 empresas pesquisadas (total das empresas no setor). 
O questionário aplicado à pesquisa de campo foi estruturado em duas partes. A primeira parte abordou a caracterização da atividade, com destaque para as diferentes etapas do processo produtivo, a fim de identificar, associadas a essas etapas, as principais implicações socioambientais decorrentes da atividade. Um segundo bloco englobou questões referentes à implementação de práticas de responsabilidade socioambiental (RSA) das empresas do setor. Estas últimas, divididas em seis dimensões relativas a: Melhoria da qualidade ambiental; Educação e conscientização ambiental; Minimização de entradas e saídas; Gerenciamento dos impactos sobre o meio ambiente; Compromisso com a melhoria do ambiente do trabalho; Compromisso com a responsabilidade social.

Ainda, para a aplicação da segunda parte do questionário junto às empresas, com o objetivo de identificar em que medida estas fazem uso dos indicadores de RSA, utilizaram-se respostas do tipo likert, onde os ceramistas apontavam: "Nunca”, "Quase Nunca”, "Às Vezes", "Quase Sempre" e"Sempre" executarem as ações correspondentes de RSA.

Como metodologia de análise, à medida em que são apresentados os aspectos produtivos do segmento e suas implicações ambientais, destacam-se as respectivas ações de RSA adotadas pelas empresas do setor de cerâmica vermelha, com os percentuais de incorporação dos indicadores.

\section{Setor de cerâmica vermelha na RM Cariri: aspectos produtivos, implicações ambientais e ações de responsabilidade socioambiental}

\subsection{Características iniciais do setor}

É bastante comum na região, principalmente na cidade de Crato, as unidades produtivas terem origem familiar, o que é facilitado através da posse de terras pelas famílias, garantindo fornecimento de matéria-prima de base local. A grande maioria encontra-se localizada em áreas periurbanas ${ }^{2}$, o que torna o fator ambiental desse segmento ainda mais determinante para a garantir a qualidade de vida da população.

Em torno de 50\% das empresas tem menos de 10 anos de funcionamento, refletindo que ocorreu uma reestruturação no setor. $A$ unidade mais recente encontra-se em funcionamento há cinco anos e a mais antiga foi instalada perto dos anos 1950. Em

2 Segundo Vale e Gerardi (2006, p. 236), as áreas periurbanas “seriam zonas de transição entre cidade e campo, onde se mesclam atividades rurais e urbanas na disputa pelo uso do solo". 
certos casos, houve transferência de propriedade, com a entrada de novos investidores no segmento, devido à conjuntura positiva, com forte expansão da demanda, há pelo menos uma década. O setor foi foco de empresários locais que diversificaram seu portfólio, inclusive comerciantes de material de construção, que aproveitaram conjuntura e conhecimento do mercado para atuar no ramo. A mudança do mercado, especialmente a partir de 2010, também estimulou o crescimento de unidades, antes pequenas olarias, posteriormente, indústrias em expansão.

A mão de obra disponível não tem se constituído em empecilho para a produção no setor, mas a baixa qualificação influencia a alta rotatividade constatada no segmento. Provém, em sua maioria, de trabalhadores recém-saídos do setor rural, que veem no segmento industrial um trabalho menos pesado e degradante, ao mesmo tempo em que enfrentam dificuldades de absorção em outros setores. Esses fatores contribuem para a baixa consciência ambiental que se observa nos trabalhadores.

Relativo a ações de RSA ligadas à dimensão "Educação e consciência ambiental", 89,5\% das empresas admitem "nunca" terem utilizado processo de formação ou campanha com seus empregados sobre temas que despertem a consciência ambiental. Ainda nesta dimensão, a ausência de ações em prol de melhor qualificação da mão de obra no entendimento e trato das questões ambientais que envolvem o setor pode ser constatada no percentual de $94,7 \%$ das empresas "nunca" utilizarem campanhas de reciclagem, redução do consumo de água e energia e consumo consciente. Como indicador da dimensão "Gerenciamento de impactos sobre o meio ambiente", 89,5\% das empresas apontam que "nunca" discutiram ou apresentaram aos seus empregados os impactos ambientais causados por seus produtos e serviços.

Mão de obra temporária se encontra disponível acompanhando a sazonalidade da produção agrícola, aumentando, portanto, em períodos de larga estiagem. No município de Jardim, foi constatada uma retração nos trabalhadores disponíveis durante períodos em que é a intensa a produção na fronteira agrícola do Centro-Oeste, principalmente no estado de Goiás.

Todavia, junto às unidades com maior diversificação de produtos e maior nível de automação, que demandam trabalhadores mais especializados, a baixa qualificação da mão de obra se impõe como gargalo não somente para a produção, mas se constitui empecilho ao próprio processo de automação. A falta de uma política de qualificação e atualização dos trabalhadores deixam vulneráveis etapas estratégicas da produção, como a queima dos 
produtos, devido à dificuldade na lida com os fornos. A inexistência de políticas de retenção de mão de obra especializada é outra marca do setor, que perde trabalhadores para outras regiões e mesmo para outros segmentos da indústria regional.

Essa realidade pode ser constatada por indicadores relativos à dimensão "Compromisso com a melhoria do ambiente de trabalho". Sobre o compromisso com o desenvolvimento profissional e a empregabilidade da mão de obra, 63,2\% das empresas "nunca" e 26,3\% "quase nunca" fazem uso de práticas de sua promoção. 68,4\% das empresas "nunca" fizeram uso de política de remuneração, benefícios e carreira (26,3\% e 10,5\% responderam "quase nunca" e "às vezes", respectivamente). Ainda, sobre atração e retenção de mão de obra, a atuação das empresas no uso deste indicador se distribui desta forma: $47,4 \%$ responderam "nunca", 36,8\% "quase nunca", 10,5\% "às vezes" e 5,3\% "quase sempre".

Apesar da baixa qualidade do emprego, os números do mercado de trabalho no setor, em 2016, revelaram a existência de 1007 postos de trabalho, dos quais $80 \%$ constituíam-se de empregos permanentes e quase 200 postos flutuavam como emprego temporário (dados da pesquisa).

O principal produto do segmento cerâmico local é o tijolo de oito furos, mas identifica-se a produção de variedade de tijolos, lajotas, revestimentos e telhas (colonial, portuguesa, americana e romana).

São produzidas em torno de 20 milhões de peças mensalmente, considerando tijolos, lajotas e telhas (Tabela 1). Conforme informações coletadas, o setor tem trabalhado com $72,62 \%$ da sua capacidade de produção, o que corresponderia a uma capacidade produtiva de 27.760 mil peças mensais. O principal destino são os municípios de outros estados do Nordeste, $46 \%$ do mercado e, da própria região, $45 \%$. Apenas $9 \%$ da produção é vendida no restante do estado do Ceará.

TABELA 1 - DISTRIBUIÇÃO ABSOLUTA E RELATIVA DOS PRINCIPAIS PRODUTOS DO SETOR NÚMERO DE PEÇAS (EM MIL UNIDADES)

\begin{tabular}{ccc}
\hline Produto & Quantidade & Percentual \\
\hline Tijolos & 16.160 & 80,2 \\
Lajotas & 650 & 3,2 \\
Telhas & 3.350 & 16,6 \\
\hline Total & $\mathbf{2 0 . 1 6 0}$ & $\mathbf{1 0 0}$ \\
\hline
\end{tabular}

FONTE: Os autores (2016). 
Os equipamentos presentes no parque produtivo são majoritariamente produzidos no Sul e Sudeste do Brasil. Um dos entrevistados relata aquisição de maquinário produzido na região, na cidade de Missão Velha. Em processos de automação mais modernos, como a introdução de secadores tecnologicamente sofisticados, já se identificam equipamentos da fabricação venezuelana, onde se encontram parques produtivos e tecnológicos mais avançados em nível de América Latina.

Todavia, o dia a dia do processo produtivo da região é marcado pela aquisição de maquinário reutilizado, de segunda ou terceira linha, originário de outras regiões do estado e mesmo do segmento local. Por consequência, comprometem-se produtividade, qualidade de produtos e competividade; aumenta-se o custo com manutenção e diminui a eficiência energética. Adicionalmente, aumentam-se os ruídos sonoros e os riscos de acidentes de trabalho.

O tempo de substituição de equipamentos tem correspondido em média a 14,8 anos, sendo basicamente para suprir o desgaste natural destes ou para repor peça básica da produção. Apenas um ceramista aponta a necessidade de ganhos tecnológico como fator para substituição de equipamento, com vista, basicamente, a melhorias na produtividade, e nenhum cita qualquer motivação ambiental. Assim, quase a totalidade dos produtores não relata reposição de equipamentos ou substituição por modelos mais modernos e eficientes, dada utilização por toda vida útil deles; apenas é relatada a troca de peças de reposição.

Na dimensão "Gerenciamento de impactos sobre o meio ambiente", a substituição de equipamentos e atualizações tecnológicas, visando à diminuição de impactos ambientais, "nunca" e "quase nunca" foram utilizadas por $84,2 \%$ das empresas.

Constata-se a escassa manutenção de equipamentos, que muitas vezes, ao apresentarem defeitos e na possibilidade de não interromper a produção, mesmo com a queda da qualidade do produto, não vão a conserto ou são substituídos, dado o custo dessa manutenção (conforme fala dos produtores). Ademais, é notória a dificuldade de assistência técnica local. Desta forma, o tempo médio entre manutenções de equipamentos no setor é de quatro semanas, apontado, pelos produtores, como necessário para manter o fluxo da produção, evitando interrupções. Apenas duas unidades indicam, como fator para manutenção, a preocupação com a qualidade das peças. Mais uma vez, fatores ambientais não são apontados, pelos ceramistas, como determinantes de melhorias no processo produtivo, nem de incorporação de práticas de responsabilidade socioambiental.

Relativo a manutenções periódicas de equipamentos visando à diminuição de impactos ambientais, 79,9\% dos ceramistas"nunca" e"quase nunca"levaram em consideração esse aspecto em seu parque produtivo. 
Vale ressaltar que manutenções mais especializadas demandam técnicos, principalmente de outras regiões, o que se torna inviável para grande parte dos produtores, elevando sobremaneira os custos de produção. Entre as empresas de maior porte, uma delas relata a contratação permanente de um funcionário que antes realizava visitas e manutenções periódicas, advindo de empresa especializada extrarregional, avaliando o custo de oportunidade entre gasto com intervenção temporária versus funcionário permanente.

A manutenção mais frequente ocorre nas boquilhas das extrusoras, onde pequenos defeitos podem inviabilizar lotes e atrasar o processo como um todo. Não se utiliza qualquer tipo de silenciador nos equipamentos para a diminuição de ruídos sonoros.

É frequente, mesmo de forma rudimentar ou improvisada, a presença de oficinas para pequenos consertos nas próprias unidades, não sendo disponibilizada mão de obra específica para tais funções, mas uma espécie de trabalhador "faz tudo", geralmente ligado ao processo produtivo.

Particularmente nas unidades que produzem algum tipo de telha, devido ao alto desgaste nas matrizes, os produtores já têm implantado, na própria fábrica, uma matrizaria particular, contribuindo para melhoria de qualidade, produtividade, redução de custos e evitando impedimentos temporários no processo de produção, garantindo melhor competitividade no segmento.

\subsection{0 processo produtivo}

O processo produtivo do setor de cerâmica vermelha na região é heterogêneo, considerando-se as diferentes unidades produtivas, a diversidade de produtos ofertados e seu grau de aprimoramento tecnológico.

Tendo como referência o conjunto dessas unidades, são encontrados os seguintes maquinários e equipamentos no setor:

a) No trato na lavra e transporte da argila - escavadeiras, retroescavadeiras, pás carregadeiras, retro de esteira, caminhões-pipa, caminhões-caçamba.

b) Na produção de tijolos e telhas - caixão alimentador, destorroador, desintegrador, laminadores, misturador, extrusoras (marombas), cortadores, esteiras, trituradores de lenha e elevadores de abastecimento.

c) Para o armazenamento e transporte no interior da unidade-motorrebocadoras, carros de mão, automatismo de carga, gaiolas sobre trilhos. 
d) No transporte e distribuição de peças finais - caminhões.

e) Para o funcionamento das atividades - geradores de energia.

\subsection{Tratamento da argila}

Um total de 18 empresas trabalha com jazida própria de extração da argila. Apenas uma fábrica realiza compra de terceiros. O volume mensal de argila consumido nas indústrias locais é de 40.320 toneladas.

A extração e manipulação da argila nas lavras é feita basicamente com o uso de pás carregadeiras e retroescavadeiras. É importante atentar que é recomendado o uso de tratores de esteiras na realização de escavações (NUTEC, 2001), encontrado em apenas quatro unidades produtivas. $\mathrm{O}$ manuseio da argila através de pás carregadeiras e retros deveria ser direcionado basicamente para carregamento de caminhões-caçamba e alimentação de caixão alimentador, para melhor distribuição e armazenagem de material. Porém, a utilização improvisada das pás diminui a eficiência no processo, sobrecarrega o próprio sistema hidráulico da máquina, aumentando-lhe o desgaste, diminuindo-lhe o tempo útil, causando interrupções desnecessárias do processo e ocasionando defeitos, demandando, consequentemente, recursos para sua manutenção. Ademais, o manuseio ocorre sem maiores preocupações com critérios ou planejamento técnico prévio. Ambientalmente, reforça processos erosivos, com maior alteração da paisagem e maior dificuldade para posterior recuperação. Atentar, ainda, que maquinário com inadequada utilização também constitui risco para mão de obra, aumentando as chances de acidentes de trabalho.

Aqui, destaca-se, na dimensão "Compromisso com a melhoria da qualidade ambiental", que 78,9\% das empresas "nunca" ou "quase nunca" utilizam processos para mapeamento da qualidade ambiental, como estudos de solo, jazidas, reflorestamento etc.

A extração é feita por lotes, podendo uma mesma área apresentar diferentes tipos de materiais, com diferenciado teor de argilominerais (barro forte) ou maior teor de sílica (barro magro, "puage"). Apenas 10 produtores afirmam proceder a algum tipo de recuperação da mina e quase todos estes ressaltam só realizarem recuperação da área após sua plena utilização, o que pode acentuar os processos erosivos. A recuperação se dá basicamente com o recapeamento da área com a camada imediatamente superior, removida no início do processo. Como as camadas superiores de argila são geralmente as que melhor se adaptam à conformação, a exploração da área pode ocorrer sem o devido aproveitamento dos lotes ou 
cava, contribuindo para a ineficiência no uso de recursos pra exploração e, principalmente, para processos de degradação ambiental. A proximidade de jazidas da autoestrada também se constitui enorme risco de processo erosivo junto a elas, configurando um cenário de preocupação para a população e autoridades locais.

Dois produtores afirmam trabalhar atualmente com a construção de pequenos açudes na área de lavra, o que se constitui alternativa de recuperação da área e benefício para a população do entorno, podendo servir como área de piscicultura. Um dos ceramistas destina material não aproveitável para constituição de massa para aterrar os lotes já exauridos na própria jazida. Trabalhos de recuperação no estilo plantio de árvores só é realizado por dois produtores locais.

Pode-se observar, portanto, através de indicadores da RSA, que na dimensão "Gerenciamento dos impactos sobre o meio ambiente", medidas corretivas de danos são limitadas no setor. O percentual de empresas que dizem "nunca" atuarem através de reparação de danos ambientais corresponde a 47,4\%. Dentre as empresas que executaram alguma ação neste sentido, 38,8\% e 10,5\% delas, respectivamente, declararam executar "quase nunca" e "às vezes" as citadas ações.

Aqui, identifica-se a forte fragilidade na atuação das empresas com vistas à proatividade ambiental, identificada por González-Benito e González-Benito (2006) como as ações voluntariamente desenvolvidas como forma de minimizar o impacto ambiental de seus processos e operações, com intervenções que vão além das exigências legalmente constituídas. Relativo ao uso sustentável da biodiversidade e restauração dos habitats naturais, as empresas adotam práticas menos homogêneas, mas a maioria $(73,7 \%)$ executa tais ações de forma esporádica (42,1\% e 31,6\% das empresas, respectivamente, responderam "quase nunca" e "às vezes").

Somente uma empresa menciona atuação junto a ONG para a preservação de fauna local. Pode-se afirmar que praticamente todos os produtores consideram que o fato de possuir reserva legal, ou seja, cumprir as exigências dos órgãos de fiscalização quanto à legalização da área, já atende aos requisitos de boa prática ambiental nesse quesito. Recuperação da área, rigor em critérios técnicos, utilização de equipamentos mais apropriados e cuidados com a saúde e segurança do trabalhador, que, nesse caso, trabalham sem nenhum sistema de proteção, como EPIs, parecem se constituir elementos secundários dentro de uma atuação com respeito ao meio ambiente. 
Neste caso, a intervenção mais responsável por parte dos ceramistas está, portanto, associada a um amplo conjunto de exigências legais colocado ao segmento, que regulamenta, por exemplo, que a procedência do principal insumo do setor (lenha) esteja dentro de ações de manejo florestal. A descaracterização de paisagens, degradação de solo etc. são resultados das atividades das empresas no trato das lavras de argila, ocorrendo, em poucos casos, evidência de recuperação de áreas degradadas. Relativo aos indicadores de RSA, a medida mais utilizada de gerenciamento de impacto ambiental no segmento passa por obrigações legais, onde $78,9 \%$ das empresas afirmam sempre cumprirem as normas legais.

Sobre a descaracterização da paisagem pela exploração da argila, esta pode ser vista sem muita dificuldade na região, já que boa parte das empresas e das lavras se encontra em áreas periurbanas, mesmo com os produtores se enquadrando em exigências legais. Não se identifica um planejamento mais complexo de extração nas jazidas, nem suporte institucional ou governamental de estímulo a medidas individuais ou coletivas de recuperação de lavras. As poucas ações nesse sentido são pontuais, amadoras, sem critérios técnicos e com baixíssimos resultados concretos.

Isso é reflexo de apenas uma empresa possuir planejamento estratégico em seus planos de negócios, incorporando, em tal planejamento, ações que envolvam a questão ambiental. A ausência de planejamento explica o fato de que $94,7 \%$ das empresas não estabelecem metas ou indicadores de desempenho ambiental, indicando também que a curto ou médio prazo não sejam avaliados os impactos de suas atividades, limitando sua ação através de medidas compensatórias ou preventivas de melhoramento ambiental.

Nesse sentido, uma das principais estratégias de promoção da RSA, apontadas na literatura como diferencial competitivo das firmas, as estratégias de planejamento e organização, via sistema de gestão ambiental, não são realidade no setor. Ao passo que também se negligenciam a identificação e gerenciamento dos riscos e obrigações ambientais (EPSTEIN; ROY, 1998; GONZÁLEZ-BENITO; GONZÁLEZ-BENITO, 2006; VOLPON; MACEDO-SOARES, 2007).

Ressalta-se serem identificadas, em outros estados, iniciativas de cooperação entre os produtores para a extração, conforme relatam ANICER e SEBRAE (2014, p. 56). O objetivo dessa cooperação é "explorar a área coletivamente. Dessa forma, simplificam a regularização (andamento de apenas um processo de registro de licença ou de concessão de lavra) e garantem o fornecimento da matéria-prima a longo prazo". Todavia, são inexistentes quaisquer ações que reflitam associações e parcerias entre os produtores. 
Na dimensão de RSA "Compromisso com a melhoria da qualidade ambiental", 100\% das empresas admitem nunca terem executado ações de cooperação com outros produtores para melhoramento ambiental.

Nessa perspectiva, a fragilidade na execução de práticas de RSA pelas empresas do setor contraria relevante proposição da literatura, que considera ferramenta fundamental na estratégia corporativa a formação de alianças ambientais, através de alianças e redes entre os diferentes segmentos em conexão com as empresas, especialmente dentro do próprio segmento produtivo (BERGER; CUNNINGHAM; DRUMWRIGHT, 2004; GULATI, 1998; HARTMAN; STAFFORD, 1998; VOLPON; MACEDO-SOARES, 2007).

No tocante à preparação da argila, em apenas uma empresa verifica-se a utilização, durante a extração e manuseio na lavra, de carro-pipa que auxilia na diminuição de material particulado. Outras duas empresas utilizam o carro-pipa na preparação da massa e na área de acondicionamento. A umidificação na fase preparatória é basicamente manual, todavia, em duas das empresas é utilizado sistema de aspersão.

Mesmo considerando a proximidade da lavra das unidades fabris, o transporte da argila é feito através de caminhões caçamba, os quais não utilizam nenhum tipo de cobertura, como lonas, facilitando a disseminação da poeira para a fábrica e, em caso de maiores distâncias, para as populações do entorno. Apenas uma empresa utiliza caminhão com lona. Ressalta-se que a distância média entre mina e fábrica corresponde a 2,85 km. Isso é reflexo do fato de que na dimensão "Responsabilidade social" nenhuma das 19 cerâmicas adotam gerenciamento do impacto da empresa na comunidade do entorno.

A preparação da matéria-prima é feita sem observância de critérios técnicos, como seleção para caracterizações tecnológicas da argila, porcionamento de tipos diferenciados etc. Tal processo é realizado apenas intuitivamente e pela observação, dependendo, quase que exclusivamente, da "experiência" do trabalhador dessa etapa, contribuindo, muitas vezes, para uma dependência de todo processo de um único profissional. Isso afeta a qualidade da massa, que tem influência direta na qualidade do produto, amplitude das perdas e no desgaste de equipamentos. Em duas unidades, onde é explícito o maior cuidado na preparação da massa da argila, a qual passa por destorroadores e laminadores, ainda na fase preparação, verificam-se perdas pouco significativas, resumidas praticamente a 1\% e $2 \%$, seja na moldagem, secagem ou após queima da peça. Em média, a perda do setor, no que se refere apenas à fase de moldagem, é de 6,5\%. 
Apenas um produtor obedece ao tempo de maturação da argila recomendado por órgãos técnicos (de seis meses a um ano), o qual também influencia na qualidade das peças. Para os demais, essa recomendação é praticamente ignorada, com amplos casos cuja maturação do material argiloso é de apenas um mês. Nesse caso, o layout e a organização das etapas do processo produtivo garantem não só eficiência, mas melhores condições de trabalho da mão de obra.

O acondicionamento adequado da argila também é uma preocupação secundária dos produtores, o que influencia na perda da qualidade do material e na umidade da massa, refletindo parcialmente no desperdício de recursos, como água, por exemplo, e no contato direto e mais frequente do material particulado com os trabalhadores.

É recomendada submissão da argila a controles através de testes de plasticidade. A peça final é submetida a testes de absorção, de rompimento ou resistência, de bitolas (dimensões). Entretanto, na região, somente cinco produtores alegam a realização de algum tipo de ensaio, não sendo especificada a periodicidade de testes, geralmente feitos no Centec, unidade recentemente extinta pelo governo do estado. As unidades que contam com laboratórios de testes próprios (três) realizam testes na argila a cada mudança de trecho na exploração da lavra.

Aqui, não se identifica nenhuma associação com produtores locais para a constituição de laboratório coletivo, já que individualmente os custos podem ser inviáveis para pequenos produtores; nenhuma ação pública para subsidiar pesquisas e laboratórios e são inexistentes parcerias com incubadoras ou laboratórios de universidades da região, mostrando a inexistência de redes de apoio em testes ou controle de qualidade, fundamentais para a competitividade do setor.

De modo geral, como reflexo da inexistência de ações cooperativas entre os produtores e destes com centros de capacitação profissional, assistência técnica e institutos de ensino e pesquisa, perdem-se oportunidades preciosas de parceria entre os ceramistas para a formação de mão de obra e melhorias em seus processos produtivos. Assim, 52,6\% dos pesquisados "quase nunca" consideram qualquer tipo de ação colaborativa e 23,6\% consideram recorrer apenas "às vezes".

Um dos produtores relata o uso de óleo na mistura da argila, justificado pelo melhor fluxo e conformação da massa junto à maromba.

Quase a totalidade da água consumida no setor ocorre durante a preparação da massa de argila. Como as unidades possuem poços próprios, os produtores não 
demonstram algum tipo de preocupação com o uso racional de água e em apenas duas plantas industriais verifica-se captação de água pluvial, através do sistema de tubulação e reservatório/cisterna. Aqui, cabe destaque, na dimensão "Minimização de entradas e saídas", o fato de que $73,7 \%$ dos ceramistas admitem "quase nunca" adotarem comportamentos de responsabilidade no que diz respeito à racionalidade no uso da água (medidas de reutilização; incorporação/ajuste de instrumentos para dosagem e controle da quantidade de água em certas etapas do processo; atualização de redes; pesquisa de vazamentos; melhoria operacional, de modo mais amplo).

\subsection{Preparação das peças}

Encontram-se, no parque produtivo, caixões alimentadores manufaturados, mas algumas unidades improvisam caixões de alvenaria ou estruturas precárias, auxiliadas com madeira. Foram identificadas duas unidades que mantinham tal estrutura. No primeiro caso, o abastecimento do caixão com argila ocorre basicamente com o auxílio de pás carregadeiras. Nos casos improvisados, são abastecidos manualmente, com o manuseio de pás e enxadas pelo trabalhador, em condição de extrema precarização. Os trabalhadores aparecem na sua rotina diária sem nenhum EPI adequado à situação.

Sobre o uso de EPI, de uma forma geral, exigidos pela NR6/78, constatou-se estarem disponíveis em todas as unidades industriais, porém, com uso extremamente limitado, apesar do trabalho de fiscalização recorrente, o que remete à baixa consciência ambiental dos trabalhadores, frente à ausência de programas de educação ambiental para eles e da inadequação dos sistemas de gestão da produção às demandas ambientais.

Através de esteiras, a massa de argila, já umidificada, é transportada para equipamentos de moagem, trituração e laminação, antes de entrar na fase de moldagem. Processos produtivos mais completos dispõem do maior número possível de equipamentos para trabalhar a granulometria da argila, de forma a diminuir, nos processos de moldagem, secagem e a própria queima, a produção de peças defeituosas.

Em alguns casos, de forma rudimentar, o material argiloso, antes de chegar a um laminador, recebe interferência de um trabalhador que desintegra torrões de argila com auxílio de martelos, por exemplo, ou de trabalhador que retira resíduos não integráveis à massa, como raízes. Identifica-se, em um dos processos, o uso de um imã para "garimpar" pequenas peças metálicas, que estrangulariam o processo, podendo causar defeitos permanentes em equipamentos. 
A observação do processo produtivo mostra que quanto maior a interferência da mão de obra, principalmente entre a moldagem e secagem das peças, maior a possibilidade de peças defeituosas ou menor a qualidade das peças.

O processo de secagem natural está presente em 100\% das unidades, e dura em média cinco dias, sendo encontrado sob mais de uma forma. A secagem sob galpões é encontrada na totalidade das fábricas. Algumas unidades possuem galpões que alternam telhado de vidro, contribuindo para acelerar o processo. Identifica-se uma unidade com galpões precários e telhado comum. Na secagem de galpões sob lonas, diminui-se também o tempo de secagem, funcionando estas como estufas.

Em certos casos, grandes ventiladores são utilizados para auxiliar na secagem. Em três unidades, com maior nível de automação, as peças que saem da moldagem vão direto para gaiolas que deslizam sob trilhos e dali são encaminhadas aos fornos, com pouquíssima manipulação pela mão de obra (automatismo de carga). A grande vantagem desse recurso é a melhoria da qualidade e menor perda de peças, visto que o manuseio contribui para má formação, defeitos e quebras. Ressalta-se que o modo de disposição e empilhamento das peças também influencia no tempo total da secagem.

A secagem artificial é encontrada em apenas cinco das fábricas. Em uma delas, é produzido calor próprio através de fornalha, distribuído por um esquema de ventilação e utilizado extrator de umidade. O tempo de secagem, com esse sistema, cai para 24h. Nas mesmas unidades, onde parte da secagem é natural, esse tempo se eleva para 4 ou 5 dias. A eficiência desse sistema não é otimizada, porque não se aproveita o calor dos fornos no processo de secagem.

Em quatro fábricas utiliza-se secagem artificial com direcionamento do calor dos fornos para o secador, marcando o processo produtivo local pelo grande desperdício de recurso energético. Estruturas desse gênero demandam recursos financeiros, tecnológicos e planejamento logístico, e o empresariado local encontra-se com pouca capitalização e disposição para grandes alterações em suas estruturas. Ressalta-se a resistência a grandes processos de inovação, que na avaliação dos produtores, agregam pouco valor aos produtos. Acrescentam, a isso, as dificuldades de acesso a incentivos e linhas de financiamento para o setor.

Sobre o desperdício de recursos energéticos (dimensão “Minimização de entradas e saídas"), vale destacar que os ceramistas não dispõem de nenhum instrumento de medição ou monitoramento do consumo de seus recursos naturais ou de produção de resíduos, fato extensivo a $94,7 \%$ dos produtores. 
Essa etapa da produção é apontada por alguns produtores como o maior ponto de estrangulamento do processo produtivo, já que depende de fatores climáticos e de espaço físico para a disposição das peças. Pelas próprias características do produto e fragilidade na sua manipulação, não é comum o recurso à formação de estoques para períodos de maior demanda. Importante também enfatizar a presença de uma sazonalidade na produção e vendas, correspondente à quadra invernosa da região, onde arrefece a dinâmica da construção civil. No caso da região, situada no Nordeste brasileiro, a demanda também se retrai nos meses de junho e julho, acompanhando o calendário das festas regionais.

Em termos de perdas, especificamente na etapa de secagem, o setor apresenta $4 \%$ de peças defeituosas, que são reaproveitadas, incorporadas novamente na preparação da massa.

Apesar de não contabilizar como perda final as etapas de modelagem e secagem, a qual só ocorre após o processo de queima, o custo econômico associado a tais peças envolve reutilização de equipamentos (desintegradores, laminadores, pás carregadeiras etc.), mão de obra, matéria-prima, como água, energia, entre outros.

A grande maioria das empresas, 74\%, utiliza o forno contínuo, do tipo Hoffman e os fatores apontados são: alta produtividade, baixa emissão de fumaça, aproveitamento máximo do calor, baixa produção de cinza e economia da lenha. Mas são encontrados fornos câmara em seis unidades produtivas, fornos abóbodas em três e forno túnel em apenas uma fábrica.

O melhor ajuste nos fornos, envolvendo a própria estrutura física, equipamentos de controle de temperatura e exaustores e sua melhor manipulação pela mão de obra, garantem que seja menor a emissão de gases. Nessa fase, a demanda por funcionários mais especializados é problema constante nas fábricas. Observam-se poucos recursos à filtragem de poluição atmosférica, cumprindo os empresários o básico exigido pelas legislações. A maioria das empresas não especifica a destinação das cinzas, geradas em menor grau quanto melhor o ajustamento dos fornos. Uma das indústrias relata destinação de cinzas para a produção de compostos orgânicos, utilizados no cultivo de hortaliças, em comunidade do entorno, beneficiando a população local.

O próprio planejamento, em termos de logística, torna o processo menos eficiente. É comum, conforme afirmam diversos proprietários, mudanças constantes na disposição de equipamentos, matéria-prima e do próprio produto a ser secado ou queimado. A lenha, que abastece os fornos, é recebida e armazenada em diferentes situações. Isso causa lentidão e descompasso na alimentação dos fornos, excessiva manipulação e consequente desgaste para trabalhadores. 
É relevante enfatizar que a otimização do arranjo físico é questão imprescindível para o melhoramento das condições de trabalho, aumentando tanto o bem-estar como o rendimento das pessoas. Assim, é perceptível, no setor, a heterogeneidade relativa ao nível de eficiência do layout das fábricas, o que se constitui grande deficiência na gestão produtiva local, com consequências negativas na produtividade, no uso racional do espaço, no deslocamento de materiais e pessoas, na qualidade de estoques e produtos, na exaustão dos trabalhadores e na própria demanda por mão de obra. Nesse aspecto, $89,5 \%$ das empresas revelaram não manusear suas etapas produtivas em busca de otimização ou o fazerem de forma esporádica (31,6\%, 21,1\% e 36,8\% das empresas declararam, respectivamente, as opções "nunca”, "quase

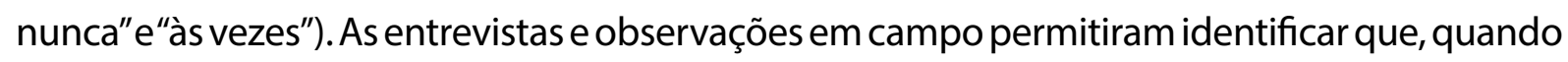
realizam ajustes do layout, as empresas têm por objetivo um maior padrão de eficiência, sem maiores preocupações com recursos humanos e ambientais.

Não se identifica cuidado adicional, nem esquemas especiais de proteção com os trabalhadoresquelidam comfornos, que permanecem expostos a um trabalhoextremamente degradante. A maior dificuldade na substituição desse tipo de mão de obra contribui para que tais trabalhadores permaneçam em atividade por longas cargas horárias, aumentando cansaço, estresse e risco de acidentes de trabalho. Pôde-se constatar diversos relatos de incêndios nas unidades produtivas, de forma extraoficial, já que aqueles controlados pela própria fábrica não são notificados aos órgãos responsáveis. Destaque para o indicador que revela que $52,6 \%$ das empresas "nunca" atuam de forma a garantir as condições de saúde e segurança de trabalho de seus funcionários e 31,6\% quase nunca atuam.

Em somente três unidades produtivas é identificado o chamado automatismo de carga e descarga, que consiste em estrutura mecânica automatizada que transporta peças e abastece fornos ou gaiolas para secagem, diminuindo a interferência de mão de obra e melhorando a qualidade das peças.

\subsection{Fonte energética}

A principal fonte energética utilizada é a lenha, equivalente a $89,74 \%$ do recurso energético do setor, obtida nos municípios da RM Cariri, mas também originária de Antonina, Várzea Alegre, Assaré, Potengi, Cariús e Jati. Apenas sete empresas possuem plano de manejo florestal próprio. São consumidos mensalmente na região $14.768,5 \mathrm{~m} / \mathrm{s}$ de lenha. 
Osceramistas declaram que $100 \%$ da lenha tem origem de manejoflorestal, conforme exigido legalmente. Porém, durante a compra, a grande maioria não exige apresentação do Documento de Origem Florestal, ou qualquer outra certificação de regularização, deixando tal exigência a cargo do órgão regulador. Na fala de alguns produtores fica clara a ciência de que parte da lenha fornecida poderá advir de áreas não legalizadas, já que a lenha é transportada por carradas.

Vale ressaltar que uma das empresas adquire lenha através de uma associação de produtores no município de Jati, processo que estimula vínculos e cooperação na região. Porém, essa é uma ação individual e espontânea, não sendo observada ou replicada em outras empresas da região. O baixo nível de integração no setor pode ser constatado através das relações com organizações locais, visto que $84,2 \%$ dos entrevistados afirmam "nunca" terem estabelecido algum tipo de parceria com associações, ONG, fundações etc.

Os fatores apontados pelos ceramistas para o uso quase que exclusivo da lenha são, além do preço, a facilidade de acesso, de manuseio e armazenamento e, principalmente, menor demanda por mão de obra. Somente dois produtores citam a lenha como recurso menos poluente e ambientalmente recomendável.

Destaca-se, ainda, que a forma de armazenamento da lenha pode contribuir para a melhoria na eficiência do processo produtivo, diminuindo estrangulamentos no processo de abastecimento dos fornos e também contribuindo para um manuseio menos exaustivo pela mão de obra. Nas unidades produtivas, é fácil constatar a heterogeneidade e falta de planejamento logístico, presente em quase a totalidade do setor.

Um dos produtores substitui quase $90 \%$ do recurso energético pelo côco babaçu, mas identifica como principal determinante para sua utilização o preço e não o fator ambiental. Diversos ceramistas afirmam que o óleo presente no babaçu é um empecilho à sua utilização, por causar problemas no maquinário, através da corrosão da estrutura metálica do forno. $\mathrm{O}$ uso do babaçu equivale a $8,84 \%$ do consumo energético do segmento.

Utilizam-se, ainda, em menor quantidade, correspondente a 1,42\% dos recursos energéticos, pó de serragem, madeira de serraria e poda de árvores.

Ressalta-se que, na dimensão "Minimização de entradas e saídas", apurou-se que praticamente todos os produtores apontaram o uso de biomassa para combustível como uma das vantagens do setor. Esse parece se constituir num dos fatores que determina que $73,7 \%$ das empresas "nunca" ou "quase nunca" façam utilização de fontes alternativas de energia e de matérias-primas menos nocivas ao meio ambiente. Em nenhuma das plantas 
constatou-se uso, por exemplo, de gás natural como fornecimento de calor, geração de eletricidade ou de força motriz, como observado em outros parques produtivos nacionais.

A utilização do conjunto de equipamentos faz do uso da energia elétrica parte importante do consumo do setor e significativo componente dos custos. Não foi constatada preocupação mais direcionada para racionalização de energia. Em duas unidades produtivas faz-se uso de geradores de energia, os quais são utilizados nos horários em que as tarifas de energia elétrica possuem preços majorados.Verifica-se que 26,3\% das empresas"nunca"utilizam medidas para seu uso racional (em seu caráter técnico, operacional e comportamental) e 63,2\% utilizam apenas "às vezes". Esse fator se revela preocupante, visto que o item compõe parcela significativa dos custos do segmento, sendo um dos bens administrados pelo setor público que mais tem sofrido majorações de preços recentemente e quando não há perspectivas de modificações estruturais na matriz energética nacional ou estadual.

\subsection{Outras informações}

O controle de qualidade ocorre, manualmente, ao longo do processo, pela observação de peças defeituosas no processo de moldagem. Tais peças voltam ao início do processo, reintegradas à preparação da argila. Após a queima, não há mais reintegração de peças defeituosas à produção, compondo os rejeitos do processo produtivo. Lotes de peças com pequenos defeitos, tipo trinca, queima irregular, alteração de cor etc., também podem compor lotes para venda, como "produtos de segunda", ou "terceira". Ainda pode-se transformar tijolos defeituosos em tijolos de quatro furos, também vendidos no mercado.

O total de perdas após a queima das peças corresponde a $4,79 \%$. Os principais fatores elencados pelos produtores são a preparação inadequada da argila, dificuldade de regulação de equipamentos e seu consequente manuseio pela mão de obra, qualidade/ dificuldade na queima, manipulação de peças pela mão de obra.

Os resíduos não reintegráveis à produção (peças defeituosas/quebradas) são destinados à pavimentação de áreas ou estradas carroçáveis, através das prefeituras municipais. Também são utilizados como entulhos na construção civil e, principalmente, passam a constituir aterros próprios no entorno das cerâmicas. Sobre as ações de RSA, grande parte das empresas $(73,7 \%)$ preocupa-se de forma esporádica (respostas "quase nunca" e "às vezes") com a destinação de resíduos, de forma a não agredir o meio ambiente. 
Em somente uma das fábricas, um sistema de câmeras eletrônicas, integrado à administração, permite o acompanhamento da produção pelo proprietário, que intervém ao serem identificados estrangulamentos na produção, permitindo controle de qualidade e agilidade no processo.

Testes sobre a qualidade das peças, como de resistência e absorção, são realizados esporadicamente e por poucos produtores. Apenas três indústrias participam de programa de certificação de qualidade dos produtos, no caso o Programa Setorial da Qualidade (PSQ), pertencentes ao Programa Brasileiro de Qualidade e Produtividade no Habitat - PBQP-H, do Governo Federal. Nesse caso, são certificadas pela Associação Nacional da Indústria Cerâmica - Anicer. A recente adesão de produtores à certificação se deu primordialmente pela possibilidade de entrada em grandioso nicho de mercado, em compras governamentais, representado pelo Programa Minha Casa, Minha Vida, do Governo Federal, que passou a exigir certificação.

Pode-se afirmar que, de modo geral, a submissão de produtos a controle de qualidade constitui-se em importante estratégia para ajuste de processos produtivos, eliminação de seus pontos de estrangulamento, diminuição de perdas e minimização de rejeitos de atividades como um todo. A análise desse indicador revela a baixa preocupação do empresário local, quando 78,9\% admitem "nunca" e 10,5\% "quase nunca" utilizarem métodos de controle de qualidade em peças acabadas. Desta forma, o indicador pouco contribui para a minimização de entradas e saídas no segmento.

Ressaltam-se, aqui, dois aspectos que contrariam a maioria da literatura acerca de práticas de RSA no ambiente corporativo. Primeiro, a relação ética e transparente da empresa com todas as partes interessadas (stakeholders) (ABREU; FIGUEIREDO JR.; VARVAKIS, 2002; AMARAL, 2005; FREEMAN et al., 2010; MAUIR; CHAN, 2002; STEURER et al., 2005). Desenvolver sinergias interativas não faz parte da realidade do setor, visto que em 94,7\% dos casos não é prática da organização o diálogo e engajamento das partes interessadas e o mesmo percentual se reproduz para ações voltadas para a formação da cidadania. Isso se reflete na quase completa ausência de estratégias de governança e transparência da gestão socioambiental, onde os mesmos $94,7 \%$ de empresas admitem não utilizarem dessas estratégias.

Segundo, a incorporação dos preceitos do desenvolvimento sustentável no ambiente corporativo e a visão ambiental sistêmica, com os três pilares para a sustentabilidade ambiental, econômico e social - através do Triple Bottom Line (TBL) (ANGEL; KLASSEN, 1999; CHEN; NEWBURRY; PARK, 2009; MAON; LINDEGREEN; SWAEN, 2010; STEURER et al., 2005). 
Na RM Cariri, quase a totalidade do setor $(94,7 \%)$ respondeu não atuar, de nenhuma maneira, com as preocupações mais estruturais acerca de processos de desenvolvimento.

\section{Considerações finais}

Identificou-se, ao longo da pesquisa, que grande parte das atividades desenvolvidas no setor de cerâmica vermelha expõe o empregado a situações de trabalho degradante, principalmente no tratamento da lavra de argila e no manuseio de fornos. A adoção de medidas que garantam a proteção e promoção da saúde no ambiente de trabalho não são prática no segmento. $O$ trabalhador da cerâmica é praticamente aquele que não teve qualificação para outro setor, "não empregável", segundo os próprios produtores, e dado o carácter mecânico e braçal da atividade, representa sempre a mão de obra disponível, demandada em períodos de expansão da produção e dispensável, em períodos de crise. Como resultado, dada a baixa especialização exigida para a maioria das funções, não há preocupação, por parte do empresariado, com a empregabilidade. O precário compromisso com as condições de trabalho reflete-se na pouca valorização do trabalhador, que aufere salários precários e não se percebem tendências de incorporação de uma política de remuneração nos planos de negócios das empresas.

Constata-se que ações empreendidas para a gestão ambiental com vistas à sustentabilidade de sistemas ecológicos, econômicos e sociais têm se mostrado ambíguas, fragmentadas e pouco capazes de responder à complexidade dos desafios colocados ao setor. De modo geral, o setor é marcado por uma baixa propensão à incorporação de progresso técnico e a processos de modernização de sua estrutura produtiva. Os determinantes vão desde a herança de certo conservadorismo familiar, à baixa capitalização da maioria das empresas em funcionamento. Contudo, o elemento imprescindível para a limitada alteração do parque produtivo é a percepção restrita de que pouco valor agregado é resultado de intervenções do gênero, principalmente quando dizem respeito a determinantes estritamente ambientais.

As atualizações no padrão produtivo, quando ocorrem, obedecem à pressão por escala, necessidade de ganhos de produtividade e conquistas de mercado. Logo, a percepção incipiente por parte do empresariado local de que a gestão ambiental pode e deve integrar estratégias competitivas limita ações que vão desde a qualificação individual dos proprietários de empresas ao planejamento ambiental, impossibilitando que medidas e ações se transformem em políticas efetivas. 
A falta de interação e cooperação entre produtores, que poderiam atuar na otimização de recursos tecnológicos e ambientais, resultando em ganhos coletivos estratégicos para o setor, isola produtores, limita intervenções de caráter preventivo e antecipatório de problemas, e inviabiliza soluções mais consistentes e duradouras que beneficiem todos os envolvidos nas atividades das empresas.

Não são sinalizadas ações contundentes com vistas à revisão dos sistemas econômicos das empresas ou ciclos de natureza contínua, de forma que sejam repensados os paradigmas de gestão e competitividade empresarial, tendo em vista novos parâmetros de inserção de padrões sustentáveis nos prismas social e ambiental. As intervenções que determinam conexões ambientais são motivadas por busca de padrões tradicionais e conservadores de produtividade e competitividade empresarial ou por imperativos das obrigações legais vigentes. Assim, medidas relativas ao uso sustentável da biodiversidade, restauração dos habitats naturais, adoções de processos menos danosos ao meio ambiente e medidas para minimização de entradas e saídas, numa perspectiva mais proativa por parte das organizações, podem estar basicamente atreladas, como evidenciado, a um amplo conjunto de exigências legais colocado ao segmento.

A timidez e anestesia dos agentes públicos e centros de formação técnica ou superior e o baixo nível de interação do segmento criam praticamente um "campo de força" em torno de ações do empresariado local que poderiam influenciar, no curto, médio e longo prazos, suas intenções com vista a uma maior cumplicidade e atuação responsável, no que se refere ao universo socioambiental. Constata-se, na prática, que as intervenções públicas são seletivas e obedecem aos movimentos de expansão do capital. Esse processo penaliza setores menos oligopolizados, regiões menos dinâmicas, tornando-as menos capazes de influenciar políticas setoriais e territoriais que as favoreçam.

Esse quadro incita que se possam realizar reflexões mais estruturais. Primeiro, o entendimento de que problemas ambientais não podem ser destituídos do processo de construção social; deve ser um imperativo para atuação conjunta de Estado, empresas e sociedade.Segundo, nãoháhorizontedemudançanessemacrossistemasocial, principalmente no que diz respeito ao âmbito empresarial (cujo pressuposto fundamental é remunerar o capital investido), se uma nova consciência ambiental não for uma premissa, um elemento intrínseco de uma nova sociedade, pautada por novos patamares civilizacionais. 


\section{Referências}

ABREU, Mônica C. S. de; CASTRO, Francisco C.; LÁZARO, J. C. Avaliação da influência dos stakeholders na proatividade ambiental de empresas brasileiras. Revista de Contabilidade e Organizações, v. 17, p. 22-35, 2013.

ABREU, Mônica C. S. de; FIGUEIREDO JR., Hugo S. de; VARVAKIS, Gregório. Modelo de avaliação da estratégia ambiental: os perfis de conduta estratégica. REAd, Edição Especial 30, v. 8, n. 6, p. 1-25, nov./dez. 2002.

ABREU, M. S. de Sá et al. O exercício da cidadania corporativa contribuindo para a transformação da realidade social da comunidade Serviluz. REBRAE - Revista Brasileira de Estratégia, Curitiba, v. 6, n. 2, p. 165-177, maio/ ago. 2013.

AMARAL, S. Sustentabilidade ambiental, social e econômica nas empresas: como entender, medir e relatar. São Paulo: Tocalino, 2005.

ANGEL, L. C. Environmental and operations management face the future. Decision line, 1999. Disponível em: www.academia.edu/748788/Environmental_and_operations_management_face_the_future. Acesso em: 19 fev. 2021.

ANGEL, L. C.; KLASSEN, R. D. Integrating environmental issues into mainstream: as agenda for research in operation management. Journal of Operation Management, 17, p. 575-598, 1999.

ASHLEY, Patricia A. et al. Ética e responsabilidade social nos negócios. São Paulo: Saraiva, 2012.

BERGER, I. E.; CUNNINGHAM, P. H.; DRUMWRIGHT, M. E. Social alliances: company/nonprofit collaboration. California Management Review, v. 47, n. 1, 2004.

BEZERRA, Francisco D.; VIANA, Fernando Luiz E.; FARIA JR., Américo R. Diagnóstico do setor de cerâmica vermelha no Nordeste. Fortaleza: ETENE/Banco do Nordeste, 2001.

CHEN, D.; NEWBURRY, W.; PARK, S. H. Improving sustainability: an international evolutionary framework. Journal of International Management, v. 15, n. 3, p. 317-327, 2009.

ELKINGTON, J. Triple bottom line revolution: reporting for the third millennium. Australian CPA, Melbourne, v. 69, n. 10, p. 75, 1999.

EPSTEIN, Marc J.; ROY, Marie-José. Sustainability in action: identifying and measuring the key performance drivers. Long Range Planning, 34, p. 585-604, 2001. Disponível em: https://citeseerx.ist.psu.edu/viewdoc/ download?doi=10.1.1.611.3871\&rep=rep1\&type=pdf. Acesso em: 12 jan. 2021.

. Making the business case for sustainability. Linking social and environmental actions to financial performance. Journal of Corporate Citizenship, v. 9, p. 79-96, 2003.

Managing corporative environment-tal performance: a multinational perspective. European Management Journal, v. 16, n. 3, p. 284-296, jun. 1998.

FIGUEIREDO, C. T. Modernidade, exclusão em áreas ambientalmente protegidas: olarias e cerâmicas no entorno do Parque Nacional da Serra de Itabaiana-SE. 175 f. Dissertação (Mestrado em Desenvolvimento e Meio Ambiente) - Departamento de Desenvolvimento e Meio Ambiente, Universidade Federal de Sergipe, Aracaju-SE, 2011.

FIGUEIREDO, C. T.; SOUSA. A. V. M. de. Conflitos socioambientais em áreas protegidas: o Parque Nacional da Serra de Itabaiana, em Sergipe. Cadernos de Ciências Sociais Aplicadas, Vitória da Conquista, n. 14 (especial) p. 141-163, 2013. 
FREEMAN, R. E. et al. Stakeholders Theory - The state of the art. The Academy of Management Annals, New York, v. 4, n. 1 p. 403-445, 2010.

INSTITUTO BRASILEIRO DE GEOGRAFIA E ESTATÍSTICA (IBGE). Censo Demográfico 2010. Rio de Janeiro: IBGE, 2012.

GONZÁLEZ-BENITO, Javier; GONZÁLEZ-BENITO, Oscar. A review of determinant factors of environmental proactivity. Business Strategy and the Environment Bus, v. 15, p. 87-102, 2006.

Perfiles de proatividad medioambiental: evidencias en empresas industrials españolas. Universia Business Review: actualidad económica, n. 5, p. 92-101, jan./mar. 2005.

GULATI, R. Alliances and networks. Strategic Management Journal, v. 19, p. 293-317, 1998.

HARTMAN, C. L.; STAFFORD, E. R. Crafting "enviropreneurial" value chain strategies through green alliances. Business Horizons, v. 41, n. 2, p. $62-73$ mar./apr. 1998.

LINARD, Zoraia Úrsula S. de A. Impactos socioambientais causados pelas atividades da indústria de cerâmica vermelha do município de Crato-CE. 145 f. Dissertação (Mestrado em Desenvolvimento e Meio Ambiente) - Programa de Pós-graduação em Desenvolvimento e Meio Ambiente, Universidade Federal do Ceará, Fortaleza, 2011.

LINARD, Zoraia Úrsula Silva de Alencar; KHAN, Ahmad Saeed; LIMA, Patrícia Verônica Pinheiro-Sales. Percepções dos impactos ambientais da indústria de cerâmica no município de Crato, estado do Ceará, Brasil. Economía, sociedade y territorio, v. 15, n. 48, p. 397-423, 2015.

MAON, François; LINDGREEN, Adam; SWAEN, Valérie. Organizational stages and cultural phases: a critical review and a consolidative model of corporate social responsibility development. International Journal of Management Reviews, v. 12, n. 1, p. 20-38, 2010.

. Thinking of the organization as a system: the role of managerial perceptions in developing a corporate social responsibility strategic agenda. Systems Research and Behavioral Science, v. 25, n. 3, p. 413-426, 2008.

MUIR, J.; REIDINGER, R.; CHAN, Y. M. Capturing sustainability issues in the oil and gas industry. Conference Paper. In: International Conference on Health, Safety and Environment in Oil and Gas Exploration and Production, 2002, Malaysia, p. 718-724.

PESSOA, José Manoel A. de P. Tecnologias e técnicas apropriadas para o desenvolvimento sustentável: o caso da indústria cerâmica de Russas - CE. 103 f. Dissertação (Mestrado em Desenvolvimento e Meio Ambiente) - Programa de Pós-graduação em Desenvolvimento e Meio Ambiente, Universidade Federal do Ceará, Fortaleza, 2004.

PORTER, M. E.; KRAMER, M. R. Strategy and society: the link between competitive advantage and corporate social responsibility. Harvard Business Review, v. 84, n. 12, p. 78-92, dec. 2006.

The competitive advantage of corporate philanthropy. Harvard Business Review, v. 80, p. 56-69, 2002.

SILVA, Valdenildo Pedro. Impactos ambientais da expansão de cerâmica vermelha em Carnaúba do Dantas. Holos, ano 23, v. 3, p. 96-112, 2007.

SILVA, A. P. M.; MEDEIROS; J. F. de. Problemas socioambientais causados pelas indústrias de cerâmicas no município de Encanto - RN. GEOTemas, Pau dos Ferros, v. 1, n. 1, p. 67-77, jan./jun. 2011.

SOARES, R. A. L.; NASCIMENTO, R. M. O processo produtivo e a qualidade do produto cerâmico estrutural. In: CONGRESSO DE PESQUISA E INOVAÇÃO DA REDE NORTE NORDESTE DE EDUCAÇÃOTECNOLÓGICA - CONNEPI, 2., 2007, João Pessoa, Anais... João Pessoa, 2007. 
SOUZA, Simone Faria de. A indústria cerâmica de Pedreira e seus impactos ambientais: subsídios para uma gestão ambiental pública. 117 f. Dissertação (Mestrado em Geociências) - Instituto de Geociências, Universidade Estadual de Campinas, Campinas, 2003.

SOUZA, Ana C. de et al. Análise do impacto ambiental originado da queima de argila com resíduos industriais. In: CONGRESSO BRASILEIRO DE ENGENHARIA E CIÊNCIA DOS MATERIAIS, 17., 2006, Foz do Iguaçu. Anais... Foz do Iguaçu, 2006.

STEURER, Reinhard et al. Corporations, stakeholders and sustainable development: a theoretical exploration of business - Society Relations. Journal of Business Ethics, v. 61, p. 263-281, 2005.

VALLE, Cyro Eyer. Qualidade ambiental: ISO 14000. 4. ed. São Paulo: Senac, 2002.

VOLPON, Claudia T.; MACEDO-SOARES, Teresia D. L. V. A. de. Alinhamento estratégico da responsabilidade socioambiental corporativa em empresas que atuam em redes de relacionamento: resultados de pesquisa na Petrobras. RAP, Rio de Janeiro, v. 41, n. 3, p. 391-418, maio/jun. 2007. 